University of New Orleans

ScholarWorks@UNO

2-1993

\title{
Older Americans' Attitudes toward the Medicare Catastrophic Coverage Act of 1988
}

Christine L. Day

University of New Orleans, clday@uno.ed

Follow this and additional works at: https://scholarworks.uno.edu/ps_facpubs

Part of the Health Policy Commons, Medicine and Health Commons, and the Political Science Commons

\section{Recommended Citation}

Day, Christine L. 1993. "Older Americans' Attitudes toward the Medicare Catastrophic Coverage Act of 1988." Journal of Politics 55 (Feb): 167-177.

This Article is brought to you for free and open access by the Department of Political Science at ScholarWorks@UNO. It has been accepted for inclusion in Political Science Faculty Publications by an authorized administrator of ScholarWorks@UNO. For more information, please contact scholarworks@uno.edu. 


\title{
Older Americans' Attitudes tomard the Medicare Catastrophic Coverage Act of 1988
}

\author{
Christine L. Day \\ University of New Orleans
}

\begin{abstract}
Congress repealed the Medicare Catastrophic Coverage Act of 1988, which expanded Medicare benefits, after vigorous protests by groups of older people nationwide. Surveys show, however, that older Americans were deeply divided in their opinions. This study examines four explanations for divisions among the elderly on this issue: symbolic politics, socioeconomic status, distrust in government, and direct self-interest. The results of probit analysis indicate that high income, younger age (under 75), Republican partisanship, and distrust in government all contributed to older Americans' opposition to government catastrophic health care coverage. Direct self-interest-that is, perceived direct impact on one's own taxes and benefits-was not significantly related to attitudes toward the program. Implications of the findings for government revenue-raising in general are discussed.
\end{abstract}

\section{$\mathbf{T}_{\mathrm{r}}$} he Medicare Catastrophic Coverage Act of 1988 was the largest expansion of Medicare since the program's creation. A year and a half later, however, the program's own beneficiaries compelled Congress to repeal the law. The financial mechanism was the reason for the outcry: beneficiaries themselves were to pay for the added benefits through Medicare premium increases and an income surtax.

Media coverage of the protests evoked images of irate senior citizens, a group sufficiently numerous and powerful to force Congress to reverse itself. Not all older Americans were outraged, however; many who were surveyed expressed support for the legislation. Nor were the political organizations representing the elderly united against the program; they were, in fact, deeply divided, with some organizations supporting the bill and others opposing it.

This is a study of Medicare beneficiaries' attitudes toward the Medicare Catastrophic Coverage Act, and the sources of opposition to that act. The results indicate that direct self-interest does not explain the opposition. Instead, distrust in government and national economic appraisals, as well as socioeconomic and partisan divisions, distinguish the catastrophic coverage plan's opponents from its supporters.

I am grateful to Maureen Casamayou, Dennis Gleiber, Charles Hadley, Steven Shull, and Carolyn Thompson for their helpful comments; to Marc Maynard of The Roper Center for Public Opinion Research for his help in obtaining the data; and to John Cosgrove for his research assistance.

THE JOURNAL OF POLITICS, Vol. 55, No. 1, February 1993, Pp. 167-177

(C) 1993 by the University of Texas Press 


\section{Political Conflict and the Catastrophic Coverage ACt}

As an expansion of Medicare benefits, the catastrophic coverage program clearly was meant to benefit older Americans. The new benefits not only helped those with acute illnesses who were saddled with sudden astronomical medical expenses, but also provided a partial substitute for private "medigap" insurance, affecting $70 \%$ to $80 \%$ of Medicare beneficiaries. Most who pay for medigap insurance themselves would have been better off financially under the new program (Rovner 1990, 527-30).

Several features of the Catastrophic Coverage Act, nevertheless, attracted some elderly opposition without building a strong core of support. First, although the program was a boon to Medicare enrollees who paid for their own medigap insurance, it duplicated many of the benefits already enjoyed by those whose insurance was fully or partially paid for by their employers - about $23 \%$ of beneficiaries. Many of those people were angry about paying higher taxes for benefits they did not need (Rovner 1989, 2715).

Second, the new benefits were financed solely by Medicare beneficiaries themselves, and the more affluent among them were to pay the most. Funding was to come from two sources: an increase of $\$ 4$ in the flat monthly Part B premium, and a progressive income tax surcharge paid by the $40 \%$ of beneficiaries who owed more than $\$ 150$ in federal income tax (Rovner 1989, 2714). Benefits were to be phased in slowly while premium and surtax collection began immediately, in order to build up a financial reserve. This was a fiscally prudent but politically unpopular move, as middle- and upper-income beneficiaries began to complain about the cost, while few people felt compelled to defend benefits they were not yet receiving (Haas 1989, 2454).

The complex array of costs and benefits generated conflicts among the organizations representing the elderly. Some national organizations supported the bill, before and after its passage, on the grounds that overall benefits outweighed the costs to the elderly. Other old-age interest groups opposed the bill, due in part to the absence of long-term care coverage, perceived by most members of Congress as far too costly. After the bill's passage, the most visible opposition focused on the financing scheme. Some established national organizations and new grassroots groups prompted an outpouring of letters, phone calls, and demonstrations demanding repeal (Day 1990, 102-104; Haas 1989; Kosterlitz 1988, 1989; Rovner 1988; Torres-Gil 1989, 76-82).

Political conflicts among the elderly, and the interest groups representing them, are not new. While many politicians and analysts have recognized the elderly's political clout and warned of impending intergenerational conflict (e.g., Longman 1985,1987 ; Hudson 1978), government spending on the elderly is not an issue that pits old against young. Older people are divided among themselves, and no more likely than younger adults to favor higher spending on old-age benefits, or to cite age-related issues as the most urgent issues facing government (Campbell and 
Strate 1981; Day 1990, 47-52; Dobson and St. Angelo 1980; Douglass, Cleveland, and Maddox 1974; Klemmack and Roff 1980). Old-age political organizations are often influential but not united; they disagree on such fundamental political questions as the extent of government social services and the role of the private sector (Day 1990; Pratt 1982, 1983).

\section{SOURCES OF CONFLiCT: Four HyPOTHESES}

Clearly, the elderly are divided even on issues that affect them most directly as a group, and these include catastrophic health care coverage. Who among the elderly supported the program, and who did not? Media accounts of the conflicts leading to the bill's repeal, as well as previous research on divisions among the elderly, suggest four explanations: (1) direct self-interest, (2) social stratification, (3) symbolic politics, and (4) distrust in government.

If direct self-interest was the primary motive for denouncing the catastrophic health care program, then the program's opponents should be those who already had equivalent private insurance coverage, and those who felt they had to pay more taxes. Indeed, retirees with employer-subsidized insurance, including retired federal employees, were among the bill's most vocal opponents (Rovner 1988; Haas 1989). The surtax also generated vigorous protests. Many elderly people evidently thought that they had to pay the full $\$ 800$ maximum surtax, even though only $6 \%$ had incomes high enough to owe that much. These misperceptions were fueled both by the complexity of the bill and by mass mailings to the elderly from organizations opposed to the program (Rovner 1989).

The other three explanations of divisions among the elderly, while related to self-interest, transcend the immediate and direct effects of the Catastrophic Coverage Act. They presume that opinions toward this and other issues are guided by people's position in society, by their partisan and ideological views, and by their attitudes toward governmental performance and economic management.

The social stratification hypothesis suggests that the more privileged elderlythose with higher incomes, more education, and a greater sense of financial security-are more likely to oppose the Catastrophic Coverage Act because they oppose government benefits and higher taxes generally. Differences in income and security levels have in fact been shown to divide older people in their opinions toward Social Security, Medicare, and government spending on the elderly in general (Day 1990, 52-61; Ponza et al. 1988; Rhodebeck and Fitzgerald 1989, 19-24).

The symbolic politics hypothesis (Sears et al. 1980) is based on ideological and partisan preferences developed early in life which guide people's attitudes toward specific issues. In the case of the Catastrophic Coverage Act, the most conservative and Republican Medicare beneficiaries are expected to oppose the bill, while liberals and Democrats should be more likely to favor the program. Evidence of such partisan divisions in elderly opinions toward old-age benefits has appeared before (Day 1990, 52-61, Rhodebeck and Fitzgerald 1989, 19-24). 
Finally, the distrust in government hypothesis suggests that opposition to the Catastrophic Coverage Act is related to public disapproval of the government's general performance and management of the national economy (see Beck and Dye $1982,175)$.

These hypotheses may overlap to some extent. The wealthiest older people, for example, were also more likely to pay higher taxes for catastrophic coverage, more likely to have previous coverage through private insurance, and more likely to be conservative and Republican. Thus, the four hypotheses are tested simultaneously through multivariate analysis.

\section{DATA AND FINDINGS}

The data for this study come from a national survey conducted by ABC News and The Washington Post, ${ }^{1}$ three months before the Catastrophic Coverage Act was repealed in November 1989. The survey includes several questions about the Catastrophic Coverage Act; those particular questions were asked only of the 169 respondents who "are currently covered under Medicare" (weighted $N=216$ ). These include $91 \%$ of the respondents 65 years of age or older, and no respondents under the age of 65 .

The survey did not include questions about political activity; thus, no portrayal of the active protesters is possible here. The survey did, however, tap respondents' awareness and opinions of the catastrophic health insurance program, permitting us to distinguish the bill's detractors from other Medicare recipients.

\section{Distribution of Attitudes tomard the Catastrophic Coverage Act}

Perusing the media shortly before the repeal of the Catastrophic Coverage Act, one often got the impression that older people hated the bill. Those who protested catastrophic coverage, however, may not have been speaking for the elderly in general. Fully $85 \%$ of those surveyed claimed to be aware of the new program, but two-thirds admitted that they did not know enough about the program to say whether they liked or disliked it, as seen in table 1 .

On other attitude questions, most elderly respondents were willing to express opinions, and were closely divided. Asked whether they got their money's worth in health benefits from the program, $34 \%$ said they did; $38 \%$ said they did not. Just over half claimed they already had some type of catastrophic health insurance before the government's new program went into effect; of those, $43 \%$ said that the new coverage under Medicare was better, while $42 \%$ preferred the coverage they had previously (see table 1 ).

The data for this paper were originally collected by ABC News and The Washington Post, August 17-21, 1989, and were made available by The Roper Center for Public Opinion Research. Neither the collectors nor the distributors of the data bear any responsibility for analyses and interpretations presented here. 


\section{TABLE 1}

\section{Medicare Beneficiaries' AtTitudes toward tHe Catastrophic Coverage Act (Percent)}

Aware of program

$\begin{array}{cr}\text { Yes } & 85 \\ \text { No } & 15\end{array}$

Like the program

$\begin{array}{rr}\text { Yes } & 12 \\ \text { No } & 23 \\ \text { No opinion } & 66\end{array}$

Must pay more taxes

$\begin{array}{rr}\text { Yes } & 36 \\ \text { No } & 56 \\ \text { Don't know } & 8\end{array}$

Getting money's worth Yes 34 No 38

No opinion 27 weighted $N=$ (216)
Would choose if optional

$\begin{array}{rr}\text { Yes } & 71 \\ \text { No } & 24 \\ \text { No opinion } & 6\end{array}$

Have private coverage Yes 58

No 39

Don't know 3

weighted $N=$ (216)

Which insurance best* Medicare Catastrophic 43 Other coverage $\quad 42$ No opinion 15 weighted $N=\quad(125)$

Source: ABC News/Washington Post National Survey, August 1989. See appendix for question wording.

*This question was asked only of respondents who already had private catastrophic health care insurance.

The big surprise of the survey, considering the hostility of the anticatastrophic protesters, is that nearly three-quarters $(71 \%)$ of the respondents said they would choose to remain in the program if it were made optional (see table 1).

Overall, then, Medicare beneficiaries' attitudes toward the Catastrophic Coverage Act were mixed; opinions were divided; and ignorance and apathy were rather widespread. Bivariate tests of each of the four hypotheses indicate that direct selfinterest is the weakest of the four in explaining these differences of opinion. The following multivariate analyses support this conclusion; indeed, the direct selfinterest explanation receives no support at all.

\section{Multivariate Analyses}

Four indicators of attitudes toward the catastrophic health care program serve as dependent variables: whether the respondents dislike the program; whether the respondents feel they are getting their money's worth; whether the respondents would remain in the program if optional; and whether the respondents prefer the government's program over their previous insurance. Because these four items do 
not scale well into a single dimension, ${ }^{2}$ and because much information would be lost to missing data if a single scale were used, multivariate analyses are run separately on each dependent variable. Probit analysis is the method of choice, since each dependent variable has been dichotomized (see Aldrich and Cnudde 1975; Aldrich and Nelson 1984).

Direct self-interest is defined in two ways: respondents' perceptions that they had to pay higher taxes under the program and previous catastrophic health insurance coverage from another source. Income, education, and age serve as indicators of socioeconomic status. Partisan and ideological placement scales represent the "symbols" guiding respondents' opinions on the substantive issues.

Finally, two indicators measure trust in government: approval of the way Congress is doing its job and assessment of the national economy. Both questions appear in the survey prior to the questions about the Catastrophic Coverage Act. There is, unfortunately, no more general question gauging trust in government; however, since protests and lobbying efforts against the Catastrophic Coverage Act were directed at Congress, this seems to be an appropriate indicator for this study. Assessment of the national economy is a less satisfactory indicator of governmental evaluation. Opposition based on economic pessimism may represent general displeasure with government economic management and social insurance schemes, but it may also simply represent a reluctance to pay more taxes when the economy is bad. In the absence of a more explicit survey question about government management of the economy, both possible interpretations should be considered.

Table 2 displays the maximum likelihood estimates, unstandardized and standardized, derived from the probit analyses. ${ }^{3}$

Distrust in government variables were statistically significant in three of the four equations. Critics of Congress were more likely to feel they were not getting their money's worth from the catastrophic health care program and to decline participation in the program if given the option. Congressional approval was, in fact, the only variable significantly related to optional participation. Appraisal of the national economy was also significant: pessimists were more inclined to dislike the program and to feel they were not getting their money's worth.

Socioeconomic variables were significant in two of the four equations, with income dominant. Wealthier respondents tended to dislike the program more and to prefer the medigap insurance they already had over the government's catastrophic insurance program. In the case of preference for previous medigap coverage, income was the only significant variable. Age was significant once: younger Medicare

${ }^{2}$ The reliability coefficient (Cronbach's alpha) for the four-item scale is .72; this is based on only 123 cases, since only respondents who had previous catastrophic coverage were asked whether they preferred that coverage over the Medicare program. Eliminating that item from the analysis yields a threeitem scale with a reliability coefficient of .65 , based on 214 cases.

${ }^{3}$ Because some of the independent variables are correlated with each other, several different equations were run, using different measurements or dropping and adding variables, for comparison purposes. In each case, the results were highly similar and the same variables were consistently significant. 


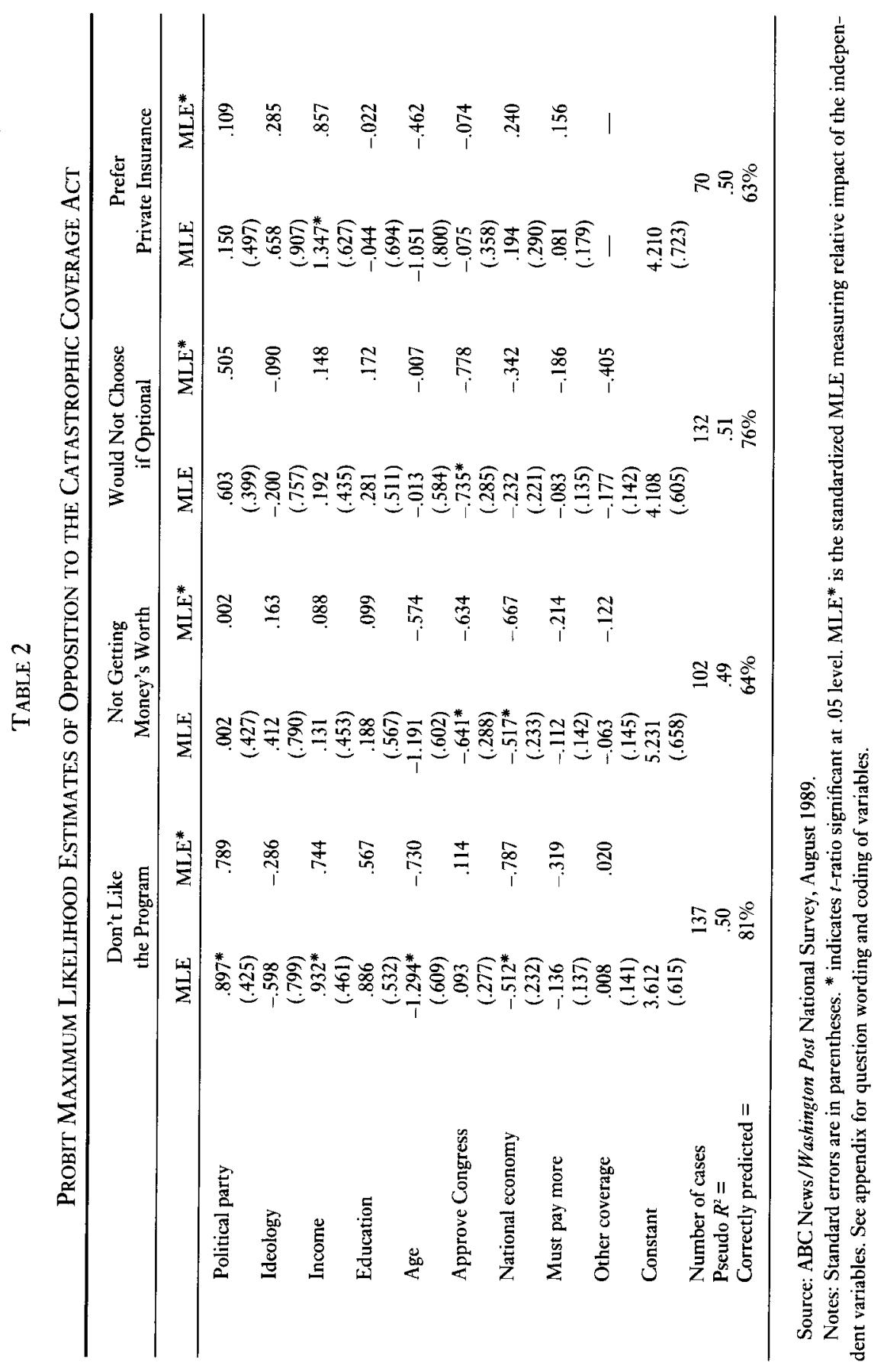


beneficiaries disliked the program more than older respondents. Education was never significant. Nor were other socioeconomic indicators-gender, race, marital status, and subjective social class-significant when entered into the equations.

Symbolic politics was pivotal in only one case: Republicans disliked the program more than Democrats. Ideology had no significant effect at all. Evidently the Catastrophic Coverage Act inspired some partisan conflict, but it was not a highly partisan or ideologically charged issue.

Divisions along direct self-interest lines, finally, were not significant in any equation. Neither higher taxes nor previous medigap insurance coverage appeared to separate the catastrophic health care program's opponents from its supporters. ${ }^{4} \mathbf{R e}-$ spondents were not asked whether their previous coverage was subsidized by their employers; nor were they asked how high their new taxes were. It may be that the effect of direct self-interest would be more conspicuous if such distinctions were made. Judging by the survey results here, however, direct self-interest does not seem to be much of a motivation for opposing the Catastrophic Coverage Act.

\section{Conclusions and Policy Implications}

Initiating policy without increasing the federal deficit is a delicate task in these budget-conscious times. The elderly backlash against the Catastrophic Coverage Act carries a message for policy-makers about two types of program funding schemes: user fees and progressive taxes.

The user fee approach to program financing, in which beneficiaries pick up the entire cost of a program, has been favored by Presidents Reagan and Bush as well as by many members of Congress as a way to avoid general tax increases. Older people's protests against the surtax in the Catastrophic Coverage Act, however, threw the political viability of any government user fees into doubt. Such user fees invite direct cost-benefit analyses by program beneficiaries; costs cannot be easily hidden. In the case of catastrophic health care, this problem intensified when some beneficiaries figured they were paying for benefits they already had (Haas 1989; Hinckley and Hill 1990).

The results of this study, however, indicate that opposition to the user fee approach may not be as pervasive as many observers think. There is little evidence in the data analyzed here that opposition to the Catastrophic Coverage Act was based on perceptions of personal cost or personal lack of benefit. Furthermore, as Hinckley and Hill point out $(1990,27)$, the user fee approach was incorporated into the 1983 Social Security bailout plan without major public backlash.

Nevertheless, the conclusion that user fees present no political problem remains debatable. Questions in this survey dealt only with opinions, not political action. If even a small percentage of the discontented Medicare beneficiaries protested the program based on their direct self-interest, they could represent a number too

${ }^{4}$ Two-stage probit models were also run, treating only the self-interest independent variables as endogenous. The results were virtually unchanged, with the self-interest variables still statistically insignificant. 
large for Congress to ignore. Indeed, user fees have been the target of vigorous protest by many different interest groups (Haas 1989, 2455).

The conclusions of this study are clearer regarding progressive taxation, in which the wealthy shoulder a heavier tax burden than the poor: the wealthy do not like it. The Catastrophic Coverage Act contained some progressive or redistributive elements: the surtax was tied to income tax liability. In addition, while benefits were not based on income, the less affluent beneficiaries were more likely to lack private medigap coverage, and therefore stood to gain more from the legislation. Opposition from the wealthy, who tend to have more political resources, as well as partisan conflict over such policies, bode ill for expanded progressive taxation in the future.

The significant impact of trust in government and national economic appraisal on attitudes toward the Catastrophic Coverage Act, however, indicates that both user fees and progressive taxes might be more acceptable to a public optimistic about the economy and confident in the government's ability and performance. Political leaders adept at cultivating public confidence-especially in a healthy economy-may enjoy more leeway in imposing otherwise unpopular taxes, with less fear of public backlash.

\section{Manuscript submitted 30 Fanuary 1991 \\ Final manuscript received 3 February 1992}

\section{APPENDIX: QUESTION WORDING AND CODING OF VARIABLES}

The following questions from the ABC News/Washington Post National Survey, August 1989, are listed in the order in which they appeared in the survey:

Do you approve or disapprove of the way Congress is doing its job? (Coding for probit analysis: $1=$ approve, $0=$ disapprove)

Do you think the nation's economy is getting better, getting worse or staying the same? (Coding for probit analysis: $1=$ getting better, $0=$ staying the same, -1 = getting worse)

And on another subject, are you currently covered under Medicare, the government's health insurance program for senior citizens?

Are you aware of the new Medicare program the government introduced this year that is supposed to cover catastrophic illness and long-term hospital stays?

Do you generally like or dislike the features of the new Medicare catastrophic coverage or don't you know enough about it to say? (Coding for probit analysis: 1 = dislike, $0=$ like or no opinion)

Since the beginning of the year, have you had to pay the government extra money, or have your income taxes gone up, to pay for that new Medicare catastrophic health care coverage? (Coding for probit analysis: $1=$ no, $0=$ don't know, $-1=$ yes)

Do you think you're getting your money's worth in benefits under the new Medicare catastrophic health care program or not? (Coding for probit analysis: $1=$ no, $0=$ yes) 
Right now participation in the new Medicare catastrophic health care program is required for Medicare recipients. If it were made optional, would you choose to remain in the program or not? (Coding for probit analysis: $1=$ no, $0=$ yes)

Before the Medicare catastrophic program went into effect, did you already have some other type of insurance that covered catastrophic illness and long-term hospital stays? (Coding for probit analysis: $1=$ no, $0=$ don't know, $-1=$ yes)

Which catastrophic coverage would you rather have: the Medicare coverage or that other coverage? (Coding for probit analysis: $0=$ Medicare coverage, $1=$ other coverage)

\section{Coding of Additional Variables in the Probit Analysis}

Political party: 7-point scale from strong Democrat $(-1)$ to strong Republican (1), with middle values converted to decimals.

Ideology: 5-point scale from very liberal $(-1)$ to very conservative (1), with middle values converted to decimals.

Education: $0=8$ th grade or less, $.2=$ some high school, $.4=$ high school graduate, $.6=$ some college, $.8=$ college graduate, $1=$ post-graduate.

Income: $0=$ under $\$ 8,000, .25=\$ 8,000$ to $\$ 12,000, .5=\$ 12,000$ to $\$ 20,000$, $.75=\$ 20,000$ to $\$ 30,000,1=\$ 30,000$ or more.

Age: Coded from 0 (age 65) to 1 (age 90), with middle values converted to decimals.

\section{REFERENCES}

ABC News and The Washington Post. 1989. ABC News/Washington Post National Survey, August 1989. Machine-readable data file. New York and Washington DC: ABC News and The Washington Post. Aldrich, John H., and Charles F. Cnudde. 1975. "Probing the Bounds of Conventional Wisdom: A Comparison of Regression, Probit, and Discriminant Analysis." American Journal of Political Science 19:571-608.

Aldrich, John H., and Forrest D. Nelson. 1984. Linear Probability, Logit, and Probit Models. Beverly Hills: Sage.

Beck, Paul Allen, and Thomas R. Dye. 1982. "Sources of Public Opinion on Taxes: the Florida Case." The fournal of Politics 44:172-82.

Campbell, John Creighton, and John Strate. 1981. "Are Older People Conservative?" Gerontologist 21:580-91.

Day, Christine L. 1990. What Older Americans Think: Interest Groups and Aging Policy. Princeton: Princeton University Press.

Dobson, Douglas, and Douglas St. Angelo. 1980. Politics and Senior Citizens: Advocacy and Policy Formation in a Local Context. Washington, DC: U.S. Administration on Aging.

Douglass, Elizabeth B., William P. Cleveland, and George L. Maddox. 1974. "Political Attitudes, Age, and Aging: A Cohort Analysis of Archival Data." Journal of Gerontology 29:666-75.

Haas, Lawrence J. 1989. "Fiscal Catastrophe." National fournal (October 7):2453-56.

Hinckley, Katherine, and Bette Hill. 1990. "Targeting Medicare Beneficiaries: The Elderly and Post1980 Legislation." Presented at the annual meeting of the Midwest Political Science Association, Chicago. 
Hudson, Robert B. 1978. "Emerging Pressures on Public Policies for the Aging." Society 15 (July/August):30-33.

Klemmack, David L., and Lucinda L. Roff. 1980. "Public Support for Age as an Eligibility Criterion for Programs for Older Persons." Gerontologist 20:148-53.

Kosterlitz, Julie. 1988. "Catastrophic Coverage a Catastrophe?" National fournal 20:2949-52.

Kosterlitz, Julie. 1989. "What Is Senator Bentsen Up To?" National Fournal 21:1055.

Longman, Phillip. 1985. "Justice Between Generations." The Atlantic Monthly, June.

Longman, Phillip. 1987. Born to Pay: The New Politics of Aging in America. Boston: Houghton Mifflin.

Ponza, Michael, Greg J. Duncan, Mary Corcoran, and Fred Groskind. 1988. "The Guns of Autumn? Age Differences in Support for Income Transfers to the Young and Old." Public Opinion Quarterly 52:441-66.

Pratt, Henry J. 1982. “The 'Gray Lobby' Revisited.” National Forum 62 (Fall):31-33.

Pratt, Henry J. 1983. "National Interest Groups among the Elderly: Consolidation and Constraint." In Aging and Public Policy: The Politics of Groming Old in America, ed. William P. Browne and Laura Katz Olson. Westport, CT: Greenwood Press.

Rhodebeck, Laurie A., and Roy E. Fitzgerald. 1989. "The Politics of Greed? The Dynamics of Public Opinion among the Elderly, 1972 to 1986." Presented at the annual meeting of the Midwest Political Science Association, Chicago.

Rovner, Julie. 1988. “Catastrophic-Insurance Law: Costs vs. Benefits." Congressional Quarterly Weekly Report (December 3):3450-52.

Rovner, Julie. 1989. "The Catastrophic-Costs Law: A Massive Miscalculation." Congressional Quarterly Weekly Report (October 14):2712-15.

Rovner, Julie. 1990. "Climbing Medigap Premiums Draw Attention on Hill." Congressional Quarterly Weekly Report (February 17):527-31.

Sears, David O., Richard R. Lau, Tom R. Tyler, and Harris M. Allen, Jr. 1980. "Self-Interest vs. Symbolic Politics in Policy Attitudes and Presidential Voting." American Political Science Reviem 74:670-84.

Torres-Gil, Fernando. 1989. "The Politics of Catastrophic and Long-Term Care Coverage." fournal of Aging and Social Policy 1:61-86.

Christine L. Day is assistant professor of political science, University of New Orleans, New Orleans, LA 70148. 
Copyright of Journal of Politics is the property of Cambridge University Press and its content may not be copied or emailed to multiple sites or posted to a listserv without the copyright holder's express written permission. However, users may print, download, or email articles for individual use. 